\title{
THE AUTHOR'S PROPER SPEECH SPHERE IN THE NOVEL OF V. DOMONTOVYCH «DOCTOR SERAPHICUS»
}

\author{
Zubets Natalia \\ Candidate of Philological Sciences, Associate Professor \\ ORCID ID 0000-0003-0498-9736 \\ Zaporizhzhia National University \\ 66, Zhukovskoho Str., Zaporizhzhia, 69063, Ukraine \\ zubetsno@gmail.com
}

The scientific research was realised on the basis of the existential and psychological novel of V. Domontovych «Doctor Seraphicus». The compositional structure of the literary text was examined by marking the distinction of main types of a speech - the one of the author and the one of the character. It is emphasized that the author's point of view is most complete and explicitly manifested in the author's proper speech, which plays a leading role in the formation of the concept of a work, characterized by evaluativity and modality. The principal approaches to the definition of the notion "author's speech» from the perspective of psychology and linguistics were named.

Since the complex functional textual speech unities - descriptions, narrations, reflections structure the author's opinion, regulate its development and ensure its integrity and completeness, then, the role of each compositional speech form in interpreting the novel's idea was established and revealed (presentation of the macrocosm and the microcosm of a man, transfer of the temporal sequence and conditionality, reflection of the author's world perception). The special attention was paid to the form of reflection as a generalized representation of the author's point of view which is universal and autonomous.

The lexical-semantic, structural-syntactic and functional-stylistic features of compositional speech forms are analyzed in this work.

Key words: author's speech, compositional speech forms, description, reflection, narration.

\section{ВЛАСНЕ АВТОРСЬКА МОВЛЕННСВА СФЕРА В РОМАНІ В. ДОМОНТОВИЧА «ДОКТОР СЕРАФІКУС»}

\author{
Зубець Наталя \\ Кандидат філологічних наук, доцент \\ ORCID ID 0000-0003-0498-9736 \\ Запорізький національний університет \\ вул. Жуковського, 66, м. Запоріжжя, 69063, Україна \\ zubetsno@gmail.com
}

Наукова розвідка здійснена на матеріалі екзистениійно-психологічного роману В. Домонтовича "Доктор Серафікус». Композииійну структуру художнього тексту розглянуто на основі розмежування в ньому головних типів мовлення - авторського $i$ персонажного. Наголошено, щзо точка зору письменника найбільш повно, експліцитно виявляється у власному мовленні автора, яке відіграє провідну роль у формуванні концепту твору, характеризується оцінністю та модальністю. Названо принципові підходи до визначення поняття «авторське мовлення» $з$ точки зору психології $i$ мовознавства.

Оскільки авторську думку структурують, упорядковують розвиток $i$ забезпечують ї̈ иілісність та завершеність складні функціональні текстово-

(C) Zubets N., 2020 
мовленнєві єдності - описи, розповіді, роздуми, то наведено $і$ встановлено роль кожної композиційно-мовленнєвої форми в розкритті ідеї твору (показ макропростору цे мікросвіту людини, передавання часової послідовності ци зумовленості, відображення світосприйняття автора). Суттєву увагу приділено формі роздуму як узагальненому представленню авторської точки зору, яке $\epsilon$ універсальним і автономним.

У роботі проаналізовано лексико-семантичні, структурно-синтаксичні та функиійно-стилістичні особливості композиційно-мовленнєвих форм.

Ключові слова: авторське мовлення, композиційно-мовленнєві форми, опис, роздум, розповідь.

\section{Вступ}

Багатогранні особистості завжди викликали інтерес у суспільстві. Такою людиною, науковцем, письменником був Віктор Петров (Домонтович). Утаємничені обставини життя, недомовленість, скритність із самого початку наклали відбиток на сприйняття, використання й оцінку його наукового доробку передусім як археолога й лінгвіста, а потім - i письменника. Неритмічність літературної діяльності, неоднозначна iï оцінка літературознавцями й критиками спричинили подальше спорадичне звернення до неї, замовчування, а згодом - забуття, незважаючи на майстерність романіста, синтетичність його творчої манери.

Попри все з виходом 1988 - 1989 рр. нью-йоркського тритомного видання прозових текстів В. Домонтовича, упорядкованих професором Ю. Шевельовим (Шерехом), зацікавлення цією постаттю набрало нових обертів у першу чергу в літературознавстві. За два останні десятиліття з'явилася значна кількість праць, у яких окреслилися поліваріативні підходи до вивчення творчості письменника компаративістський, інтертекстуальний, дискурсивний. Поступово формується цілісний аналіз художньо-філософської авторської манери, загальне дослідження інтелектуального дискурсу романістики письменника.

Сучасний стан мовознавчих досліджень художніх текстів В. ПетроваДомонтовича характеризується недостатньою до них увагою: загальний огляд індивідуального мовостилю письменника здійснив Ю. Шевельов (Шерех), онімний простір роману «Доктор Серафікус» досліджували Г. Конторчук, А. Ремез (Конторчук, Реме3, 2015), М. Федурко (Федурко, 2015). Наявність лише поодиноких праць мовознавчого спрямування зумовлює актуальність нашої розвідки.

Метою нашого дослідження $\epsilon$ характеристика розподілу сигналів авторської модальності залежно від композиційно-мовленнєвих форм (КМФ) у модерному романі «Доктор Серафікус» В. Домонтовича (Домонтович, 1947) - визнаного автора української інтелектуальної прози, що постала в 20-х роках XX століття.

\section{Матеріали та методи дослідження}

Об’єктом нашої уваги став твір прозаїка, на думку критиків, найбільш досконалий із формальної точки зору, але найскладніший у плані ідейного змісту (Агеєва, 2006; Павличко, 1999). У романі В. Домонтович торкається багатьох важливих проблем, які хвилювали людей у першій третині минулого століття: свобода людини та iii поведінки, самотність як характеристика людського буття, відносність істини, емансипація жінки, абсурдність світу тощо.

Інтерпретація художнього тексту поряд із вивченням його стилістичної будови передбачає урахування композиційно-змістової та мовленнєвої організації, адже концептуально значущий смисл виникає в результаті співвіднесення плану змісту 3 певною формою вираження. Провідну роль у формуванні концепту твору відіграють авторські оцінки об’єктів, явищ і подій, що створюють його художню дійсність.

Залучивши метод лінгвостилістичної інтерпретації, контекстуальний метод i прагмалінгвістичний аналіз фактичного матеріалу, розглянемо втілення авторського мовлення в романі, його лексичні, граматичні та стилістичні особливості. 


\section{Обговорення}

Слідуючи за М. Брандес, вважаємо, що структуру художнього тексту доцільно розглядати як динамічну систему, що утворюється за допомогою таких одиниць ментального формалізованого мовлення, як композиційно-мовленнєві форми (опис, розповідь і роздум), тональність (висока, нейтральна, знижена) й архітектонікомовленнєві форми (монолог, діалог, полілог, конструкції з прямою/непрямою/невласне прямою мовою) (Брандес, 2004: 74). Названі складники виявляються у двох основних мовленнєвих потоках - авторському та персонажному, які доповнюються контамінованим або змішаним мовленням. Дослідники структури тексту відзначають, що всі вони об'єднані образом автора. Зокрема, В. Кухаренко зауважує, що художній твір як продукт пізнавальної діяльності автора «обов'язково й повсюдно містить авторське ставлення, тобто оцінність і модальність. Вони виявляються на всіх без винятку ділянках і у всіх типах викладу, але в прямій, найбільш відвертій формі вони представлені у власнім мовленні автора» (Кухаренко, 2004: 134). А. Корольова вважає суб'єктом мовлення в художній комунікації титульного автора 3 його наміром передати власний естетичний ідеал через внутрішньотекстовий коментар, що втілюється в авторських міркуваннях, відступах (Корольова, 2003: 11).

Під авторським мовленням традиційно розуміють текст, у якому митець «безпосередньо характеризує зображувані події та відповідні образи» (Літературознавчий словник, 2007: 15). У межах авторського мовлення структурують думку, впорядковують іiі розвиток і забезпечують цілісність такі функційні текстовомовленнєві єдності, як композиційно-мовленнєві форми, 3-посеред яких зазвичай виокремлюють «опис», «розповідь» і «роздум». Основне сюжетне навантаження приймає на себе розповідь, точне, яскраве уявлення про предмет мовлення дає опис, а позицію автора найповніше втілює роздум.

Аналізуючи мовну структуру інтелектуального роману «Доктор Серафікус» В. Домонтовича, який поєднує в собі різні жанри (роман, есе, елементи наукової доповіді, промова), мовні стилі (художній, публіцистичний, науковий, елементи офіційно-ділового), звертаємо особливу увагу на сигнали авторської модальності. Їх розподіл нерівномірний і суттєво залежить від композиційно-мовленнєвих форм (моделей комунікації, спрямованих на донесення інформації до читача), які спрогнозовані різноманітними засобами психологізму: психологічними портретами, пейзажами, снами, мареннями, спогадами, непрямим мовленням.

Дослідники, які зосередили увагу на другому творі В. Домонтовича «Доктор Серафікус» (В. Агеєва, Ю. Загоруйко, Н. Мариненко, С. Павличко та ін.), з-посеред цілого ряду провідних рис поетики роману, що засвідчують його інтелектуалізм, філософський підтекст, перевага думки над формою (текст постає як суперечка, дискусія; наявні широкі відступи, розлогі промови на філософські теми), іронічність художнього вираження, скептичність в оцінках, схематизація почуттів, поглядів і психічних станів, використання прийомів маски й пародії, розмивання межі між світом реальним та уявним, переосмислення міфів і відомих літературних творів - називають також відчутність голосу автора. Відзначимо, що в аналізованому творі це втілюється в різних архітектоніко-мовленнєвих формах.

\section{Результати дослідження}

Основою авторського монологічного мовлення в романі «Доктор Серафікус» $є$ «розповідь» - композиційно-мовленнєва форма, яка «бере на себе основне сюжетне навантаження, повідомляє про дії та стани, що розгортаються» (Кухаренко, 2004: 141). Жанр роману зумовлює кількісне переважання в аналізованому творі цієї КМФ (42\%), утілюючи яку автор відображає навколишній світ через послідовність дій персонажів, що й створює динамічне й акціональне зображення. Це своєрідний вертикальний зріз художнього твору.

Хоч у романі йдеться про конкретний відтинок часу - кінець 20-х років ХХ століття, у сімнадцяти його розділах розповідається про події, що відбувалися 3 
героями упродовж їхнього життя у хронологічній послідовності. Зауважимо про суб'єктивний характер розповіді в цьому сенсі, адже автор обирав ситуації чи історії на власний розсуд. Так ми дізнаємося про життя Вер, Корвина ще задовго до описуваного часу. Щодо головного героя Комахи, то читач простежує причиново-наслідкові відношення подій, що відбуваються в його житті, за доволі короткий проміжок часу друга половина 20 -х років.

Завдяки розповіді дія в романі змінюється, прискорюється, уповільнюється. Будуючи сюжет, В. Домонтович припиняє розвиток окремих ліній, як-от Комаха та дівчинка Ірця, чи уриває твір, написавши, що це кінець першої частини, бо вже не станеться нічого цікавого. Динамізм розповіді забезпечується тим, що текст насичений історичними паралелями (згадки про філософів, учених, письменників, художників), порівняннями з різними епохами (доба кватроченто) і мистецькими течіями (кубізм, супрематизм, філологізм), творами (малюнки Рембрандта і Тараса Шевченка, твори Карло Гоцці та Поля Валері, етюди Стравинського). Відтворення сюжету в романі відбувається не у зв'язку з історичними подіями, а через залучення досягнень світового та українського мистецтва, наукової думки на той період.

КМФ «розповідь» має особливості не лише в побудові, а й у доборі мовних засобів. Зміна подій у розповіді пов'язана з плином часу, що передається дієсловами відповідних часових форм (теперішнього та минулого часу). Для розповіді характерне широке вживання іменників-власних назв (імена та прізвища; топоніми та ергоніми), назв абстрактних понять тощо. В. Домонтович прагне сформувати чітку картину відповідного періоду, коли [...] після хаосу й безладдя світової й громадянської воєн, життя, здавалось, увійшло нарешті в стале річище. Бурхливі хвилі життєвого моря втихомирились, i поверхня простяглася рівна, блискуча (Домонтович, 1947: 95). Органічно вплітаються в канву роману іронічні зауваження автора про науковців колег доктора Серафікуса ([...] наукова діяльність була так само не більше, як тільки приміткою до науки (Домонтович, 1947: 94), про життя різних верств населення (Люди тішили себе ілюзією своєї власної самодостатности [...] Вони працювали, жили, купували килими, меблі, валюту, будинки, пишались один перед одним ситщем і шовком на оправах своӥх книжок (Домонтович, 1947: 95-96). Перебіг подій у романі подається крізь призму суб'єктивного, емоційно й іронічно: Колишні типи концертів одмирають, музика механізується, мистецтво набуває спортивного характеру. Фізкультура й спорт успішно конкурують з виставами, футбольні й баскетбольні змагання на стадіоні одбивають відвідувачів з театру, пляж здається привабливішим од балетного спектаклю. Дівчина, щзо стрибає у воду з трисажневої вежі, викликає не менше подиву, як балерина з ї̈ вишуканими пуантами й крицевим носком (Домонтович, 1947: 58).

Образність у розповіді створюється за рахунок нечисленних, але виразних епітетів (трималася протекціонально, епікуреїстична легковажність, духовиті десу, серафічний Комаха). Нерідко письменник творить оригінальні метафори в основі яких - ключові чи актуалізовані часом слова, як-от прапор: В теорії нової культури вони вводили апологію людини, ї̈ бажань та ї̈ активности. На прапорі свого ентузіязму вони писали: активність людини (Домонтович, 1947: 55), Для обдарованішої, інтелектуально розвиненішої цे духовно активнішої меншости прапором став філологізм, рафіноване культурництво, олександринізм (Домонтович, 1947: 63), Прапор праці він підносив як гасло своєї книжкової ізольованости (Домонтович, 1947: 113) [жир. шрифт - Н.3.]. Отже, розповідь у «Докторі Серафікусі» $є$ досить динамічною та подієвою.

Розвиток предметно-зображувального аспекту розповіді призводить до появи іншої моделі авторської комунікації - КМФ «опис», яка виступає тлом для відтворення сюжету художнього твору. Опис «фіксує ознаки об'єктів та суб'єктів дій та станів і тому є переважно статичним» (Кухаренко, 2004: 152). Описові фрагменти в романі В. Домонтовича $є$ виявом монологічного авторського мовлення, у якому міститься повідомлення про одночасні події, подається перелік характеристик певного предмета, 
явища, факту, відтак увага зосереджується не на діях, а на елементах навколишньої обстановки, на тих зовнішніх характеристиках чи внутрішніх ознаках людей, явищ, предметів, ситуацій, що важливі насамперед для письменника (горизонтальний зріз тексту). Незважаючи на меншу кількісну представленість цієї КМФ у досліджуваному тексті (28\%), описи входять у композицію як окремі елементи у вигляді виразних ліричних відступів, пейзажних замальовок, портретних характеристик персонажів, описів інтер'єру.

Описи макропростору (природи, місцевості, інтер'єру) розкривають подробиці життя й побуту інтелігенції, студентства, інших верств населення у відповідний період і майстерно поєднуються зі статичними, нейтральними щодо тональності розповідями про життя, інтереси персонажів твору. Такі описи можуть бути етюдними, коли увага концентрується на окремих деталях, як-от: вечеря головного героя Комахи ([...] ззів два шматки чорного хліба з шинкою, холодну котлету, щзо лишилася від обіду [...] $i$, ззівши перед сном ще пару яблук, точно о пів на одинадияту заснув (Домонтович, 1947: 21), новий будинок [...] у конструктивному стилі, кубик покладений на кубик, змінений модерн початку ХХ століття (Домонтович, 1947: 36) чи номінативний опис помешкання професора Комахи, у якому дотримана послідовність еліптичних і номінативних конструкцій (Кабінет. Велика шкуратяна канапа, піяніно, письмовий стіл, завалений паперами й книжками, щзо навколо нього на стільцяя $i$ на підлозі лежали купи книжок $i$ аж до стелі заповнювали полиці (Домонтович, 1947: 39). Це своєрідна імітація потоку свідомості. Смислове навантаження в останньому фрагменті несуть іменники і прикметники. У романі є також панорамні, достатньо об'ємні описи макропростору, наприклад, детальний опис кав'ярні, де відбувалася перша зустріч Комахи і Вер (Домонтович, 1947: 106-107), чи опис чудового осіннього ранку в саду, куди вони прийшли на чергове побачення (Домонтович, 1947: 125). Авторська оцінка в таких описах майже не відчутна. Розповідь у В. Домонтовича може доповнюватися динамічним описом, як-от приголомшливе враження (емоційний стан) сусідки Серафікуса від його необлаштованого житла. Автор транслює це так: Кінець-кінцем цзе дрібниці: поставити на піяніно квіти, придбати каламар, переставити меблі, подбати, щчоб вимили вікна, повісити лямбрикони, витерти порох з книжок, стільців, піяніна, прибрати зі столика в кутку кімнати синього Греца, брудний посуд, пляшку $з$ гасом, иматки хліба, невитертий почорнілий ніж, масло в пергамені, чайник, иукор у папері, пообмітати павутиння з ніжок фотеля, викинути розбитий і притрушений курявою абажур (Домонтович, 1947: 39). У наведеному фрагменті зміст відтворюється за допомогою внутрішніх просторово-часових зв'язків.

Доречно вписуються в розповідь або супроводжують роздум фрагментарні та розгорнуті пейзажі, які набувають психологічного забарвлення, перебуваючи в тісному взаємозв'язку з почуттями, вчинками героїв і оформлюючи їхні психологічні портрети, що перетворює абсолютно несентиментальний дискурс роману на глибоко емоційний $\mathrm{i}$ чуттєвий. Ось яким бачимо головного героя 3 перших рядків: Мінливо й мляво перебігають світлі струмки на великій круглій фонтанній мушлі. Зміна білявих струмків в абстрактних арабесках тіней розбиває увагу своєю безпредметністю. Перебіг тіней, падіння бризок, плюскіт води символізують для Комахи усталений спочинок на півгодини в скверику. Коли він, напрацювавшись у бібліотеці, повертається додому (Домонтович, 1947: 7).

Якщо Серафікус постає у зв'язку з мінливо-млявим Києвом, то Вер і Корвин асоціюються 3 рожевим шумуванням заходу: За річкою, за містом, над горами здійнялась гієратична чинність опрозорення міста: громади кам'яниць кучерявилися в золотому диму, в легких безшумних рухах вони линули назустріч пінявим хмарам, $i$ рожеві кармінні хмари пірнали в глибинну порожнечу річкового скла. В рожевому шумуванні заходу ось-ось, здавалось, усе потече повз землю в безмежність нескінченних просторів (Домонтович, 1947: 82).

Нерідко пейзажні описи в романі створені шляхом інтенсивного використання колористики, яка підкреслює емоційну авторську оцінку: Голуба блакить лилась у 
вікно, сиві голуби змахували блакитними крилами й відлітали, танули в срібній блакиті. Десь іздалека над пальовими горбами полів дзвонили срібним сріблом дзвони (Домонтович, 1947: 124). Образність таких описів підсилюється нанизуванням синонімів, однокореневих слів, повтором звуків, інтонаційним малюнком, наприклад: За яром, за кручею, за клубками осінніх темно-червоних квітів голубіла річка, голубіло небо. Голубіла, голубіла глибока блакитна далечінь. Осінь. Музика. Сонце! Тиша! (Домонтович, 1947: 127). Збільшення функційно-образного навантаження пейзажних описів відбувається за рахунок уживання таких мовностилістичних фігур, як порівняння, протиставлення, метафорично-метонімічні перенесення: В ясному тихому прозорому повітрі скрипки звучали підкреслено чітко, як коштовні ц̌ рідкі страдіваріюси: немов земля, небо, дерева з золотим листям були декою скрипки, $i$ загублену тайну медовожсвтого прозорого ляку, щзо звучанню страдиваріюсівських скрипок надає таємничої вишуканости, несподівано розгаданої й розлитої в густій прозорості насиченого ляковим розчином осіннього повітря (Домонтович, 1947: 125).

Письменник використовує колористику в портретних характеристиках героїв, наприклад, у Вер - смагляво-оливкове обличчя, рожево-жовті пелюстки тонких $i$ довгих пальців, у Комахи - біле з жовтуватим відтінком волосся.

Портрет у В. Домонтовича завжди містить експліцитну авторську оцінку та модальність. У романі портрети героїв постають у всій їхній багатогранності (моральній, емоційній, психологічній). Наприклад, в індивідуальних розгорнутих портретах передається мікросвіт людини (зовнішність, вік, психологічний стан) відчувається ставлення автора (симпатія, прихильність, зневага чи осуд). При цьому тональність викладу може бути високою або зниженою, наприклад: Світла шатенка, висока на зріст, Тетяна Миколаївна Беренс не була гарна, але м'який і ніжний колір обличчя надавав їй відтінку принадної задушевности й ясної теплоти (Домонтович, 1947: 77). Прикметною рисою стилю В. Домонтовича $є$ розподіл по всьому тексту портретних украплень, штрихів у вигляді характерологічних деталей чи авторського коментаря, що з'являються в розповіді або пов'язуються з роздумами (наприклад, у дівчинки Ірці - черевце, рученята, прозорі $і$ ясні очі; художник Корвин - високий $i$ тонкий, подібний на розкриті ножиці, із гострим, як у Гоголя, носом..., у нього струнка постава, тонка темна рука; у Вер - темна квітка обличчя, тонкий чітко окреслений ніс, побудований з блиском холоду, вона висока на зріст, елегантна; на характерні деталі зовнішності головного героя Комахи натрапляємо впродовж усього роману, причому лише один раз - у XII розділі - помічаємо позитивні штрихи в його портреті) за допомогою нечисленних тропів (переважно епітети, прийоми порівняння і протиставлення), що зумовлено, на нашу думку, екзистенційно-психологічним дискурсом роману. Такі штрихи в характеристиці Комахи, як абстрактний, вигаданий, безплотний, химерний, ичиклоп, дід з обличчям хлопчика, Ірці - огрядненька, пухка, рожева, ясноока й ясноволоса або Тасі - білява, товстенька, приємна, гарна, проста й лагідна, засвідчують відповідно зневажливе або прихильне ставлення автора до своїх героїв. Крім цього, індивідуальні описи у творі представлені також популярним викладом життєпису окремих персонажів (Комахи, Вер, Корвина), що нагадує діловий стиль, якому притаманна точність, послідовність, безпристрасність.

Існує думка науковців про окремішність, цілковиту самостійність і універсальність КМФ «роздум» (Кухаренко, 2004; Розанова, 1996). Вона знаходить підтвердження під час аналізу роману «Доктор Серафікус». Суть цієї КМФ полягає в послідовному, зв'язному передаванні думки про факти та явища довкілля шляхом установлення між ними причиново-наслідкових зв'язків. У романі розмірковує безпосередньо автор або думки персонажів опосередковано представлені в авторському мовленні. Роздум широко представлений у творі В. Домонтовича (30\%) й може оприявлюватися в одному - двох абзацах або розгортатися на кількох сторінках чи в цілому розділі, тоді він відповідає правилам побудови цієї КМФ: тема - аргумент - висновок. У таких монологічних повідомленнях оповідач або персонажі розмірковують про сенс буття, кохання і зраду, про дружбу між людьми, моральні 
принципи, мистецтво і культуру тощо - це головна думка роздуму, в його основній частині міститься умовивід, що відображає хід думок, а завершує фрагмент, який співвідноситься з головною думкою й випливає 3 міркування. Розгортання роздуму в художньому тексті - вільне. Наприклад, увесь IX розділ у романі являє собою роздум про місце та долю людини в технізованому світі (тема), в якому іiі дії зводяться до автоматизму, існує фахова відокремленість, заперечується логіка почуттів, нівелюється пошана до творчості (аргумент). У кінці розділу В. Домонтович робить висновок, що це й зумовило дивакуватість доктора Серафікуса - [...] людини заперечного біологізму, «приміткового», замкненого, схематичного існування (Домонтович, 1947: 101).

Роздум у романі має узагальнене причиново-наслідкове значення й не пов'язаний 3 бігом часу (в ньому переважає теперішній час дієслів). Такі текстові фрагменти насичені образними засобами 3 незвичайним лексичним наповненням: несподівані порівняння (наприклад, доля книголюбів - як шлюбне життя (Домонтович, 1947: 9), кохання Комахи і Вер - як геометричні форми, конструкиії, екпериментальні схеми (Домонтович, 1947: 139), освідчення в коханні - як райдужний фенікс, відновлений із попелу звичайности (Домонтович, 1947: 130), паралелі з різними епохами (культурництво, олександринізм), вкраплення іноземних слів або виразів (огида пересичености перед книжками, отеє taedium libelli (Домонтович, 1947: 9), логічний культ das ewigen Welblichen (Домонтович, 1947: 78), Комашине curriculum vitae існувало як примітка до його ретельних наукових студій (Домонтович, 1947: 96), залучення термінології під час характеристики побутових подій чи звичайних явищ (почуття Вер до Комахи: Татлінівська вежа, спіраль, перехрещення площчин, геометрична формула [...] (Домонтович, 1947: 140), творення оригінальних перифраз (кохання - тонке й вишукане мереживо мистецтвва (Домонтович, 1947: 56), Пити каву й запалювати циигарки - наука не легка й відповідальна (Домонтович, 1947: 57). Ефект невимушеного емоційно наповненого спілкування забезпечується також засобами експресивного синтаксису, з-поміж яких - окличні речення, риторичні запитання, парцеляція, наприклад: Людські уявлення далекого й близького умовні й відносні. Два метри - ие близько чи далеко? Може близько, а може й надто далеко! Різниия між далеким i близьким, досягненим і недосягненим, можливим і неможливим найменше залежить від усталених понять часу й простороні. Легше з Готеном здійснити мандрівку на Таїті, ніж переступити два метри між двома кімнатами. Пітьма екваторіяльних ночей прозоріша від пітьми коридору в міській квартирі. Пустелі джунглів зрозуміліші й простіші від чотирикутної пустелі міського передпокою (Домонтович, 1947: 47-48).

Нерідко в роздумах простежується майстерне поєднання фонетичних, лексичних, синтаксичних засобів образності (повтори, розмовна й наукова лексика, фразеологізми, накопичення слів однієї частини мови, різна інтонація), як у такому фрагменті: Ірияя розуміла. Вона ладна була розплакатися. Вона почувала себе ображеною. Вона надула губи. Вона одвернулась од Комахи і навіть відмовилась од запропонованої ій цукерки. Чи варто було жити в світі, їсти иукерки, спати, бути гарною й слухняною дівчинкою, якщзо твої гадки хибні й твої припущення розходяться з дійсністю? Вона пішла сумна й насумрена (Домонтович, 1947: 15).

Роздуми в В. Домонтовича мають ознаки публіцистичності, оскільки містять суб'єктивні авторські міркування, засоби переконання та аргументації. Цей факт підтверджує думку Ю. Шевельова про наявність у модерному інтелектуальному романі «Доктор Серафікус» яскравих рис есе (Домонтович, 1947: 138).

Оригінальний хід думок, цікаві розмірковування в роздумах оповідача й персонажів зумовлюють глибокі, філософськи осмислені висновки, які афористично структуровані й можуть функціювати автономно. Ось деякі з них:

Цивілізоване людство культурне в своїх мистецтвах, але воно лишилося варварським у своїх почуттях $і$ бажаннях (Домонтович, 1947: 56),

Бути жінкою - мистецзтво, як грати в пінг-понт, диритувати оркестрою й брати призи на шахових турнірах (Домонтович, 1947: 56), 
Тільки з людини, певної свого права бути вільною, може вийти щзось більще, ніж урядовець, фінагент, професор, юрисконсульт, завшколи (Домонтович, 1947: 97),

Кохання - коштовний дарунок, $i$ справа не в тому, щзоб відмовлятись чи відмовляти, а лише в тому, щоб не знецінювати почуття (Домонтович, 1947: 117),

Найгірше почуття в коханні - це заздрість. Не кладіть ніколи на вагівницю даного вам і відданого іншим (Домонтович, 1947: 150-151).

У таких висловах міститься квінтесенція авторських роздумів.

\section{Висновки та перспективи}

Отже, авторська комунікація в інтелектуальному романі «Доктор Серафікус» втілюється в різних КМФ - «розповіді», «описі» та «роздумі». Вона структурує твір, забезпечує його композиційну реалізацію, відображає його часовий i просторовий континууми за допомогою різних мовностилістичних засобів (метафоричнометонімічні перенесення, несподівані порівняння, виразні епітети й оригінальні перифрази, залучення термінів під час характеристики побутових подій чи звичайних явищ), експресивного синтаксису, зміни тональності.

Жанр твору зумовлює кількісну перевагу КМФ «розповідь», яка $є$ основою авторського монологічного мовлення. Суб'єктивний характер розповіді зумовлений авторським вибором ситуацій чи історій, які він розвиває або припиняє.

В описах макропростору чи мікросвіту людини в аналізованому романі міститься експліцитна авторська оцінка (скептична чи іронічна) та модальність. Ця КМФ виступає тлом для відтворення сюжету. Описи в романі розподілені між розповідями та роздумами у вигдяді авторських коментарів, деталей або штрихів.

Широко представлена у творі КМФ «роздум». Зазвичай це невимушені, емоційні розмірковування автора чи думки персонажів. Оригінальні думки письменника про місце та долю людини в технізованому світі, про руйнування природи i мистецтва цивілізацією, духовну порожнечу особистості роблять розгляданий твір актуальним у сучасних умовах.

Відзначимо, що в інтелектуальному романі $\mathrm{B}$. Домонтовича традиційні композиційно-мовленнєві форми містять то ознаки публіцистичності, то науковості, вони постійно комбінуються і взаємопроникають.

Лінгвокогнітивний простір творів романіста може стати предметом зацікавлення мовознавців.

\section{СПИСОК ВИКОРИСТАНИХ ДЖЕРЕЛ}

Агеєва, 2006 - Агеєва В. Поетика парадокса : Інтелектуальна проза Віктора ПетроваДомонтовича. Київ : Факт, 2006. 432 с.

Брандес, 2004 - Брандес М. Стилистика текста. Москва : Прогресс-Традиция; ИНФРАM, 2004. $416 \mathrm{c}$.

Домонтович, 1947 - Домонтович B. Доктор Серафікус. Мюнхен : «Українська трибуна», $1947.175 \mathrm{c}$

Конторчук, 2020 - Конторчук Г., Ремез А. Особливості поетичної онімії в романі В. Домонтовича «Доктор Серафікус». URL : http://eprints.zu.edu.ua/id/eprint/15770 (дата звернення : 12.10.2020).

Корольова, 2003 - Корольова $A$. Лінгвопоетичний і наративний коди інтимізації в художньому тексті (на матеріалі української та російської прози другої половини XIX - першої половини XX століть) : автореф. дис. ... д-ра філол. наук. Київ, 2003. 53 с.

Кухаренко,2004 - Кухаренко B. Інтерпретація тексту. Вінниця : Нова книга, 2004. $272 \mathrm{c}$.

Літературознавчий словник, 2007 - Літературознавчий словник-довідник. Київ : ВЦ «Академія», 2007. 751 с.

Павличко, 1999 - Павличко С. Дискурс модернізму в українській літературі. Київ, 1999. $447 \mathrm{c}$. 
Розанова, 1996 - Розанова E. Композиционно-речевые формы в англоязычной художественной и публицистической прозе (сопоставительное исследование на материале произведений XIX - XX вв.) : дис... канд. филол. наук. Одесса, 1996. 167 с.

Федурко, 2015 - Федурко М. Власне ім'я в романі Віктора Домонтовича «Доктор Серафікус» : функції та різновиди. Проблеми гуманітарних наук. Серія : Філологія. Вип. 36. Дрогобич, 2015. С. 200-212.

Шевельов, 2017 - Шевельов (Шерех) Ю. Я - мене - мені... (і довкруги). Спогади. 1. В Україні. Харків : Видавець Олександр Савчук., 2017. 728 с.

\section{REFERENCES}

Ageyeva, 2006 - Ageyeva V. (2006). Poetyka paradoksa : Intertekstualna proza Viktora Petrova-Domontovycha [Poetics of Paradox: Intertextual prose of Victor Petrov-Domontovych]. 432 p. [in Ukrainian]

Brandes, 2004 - Brandes M. (2004). Stilistika teksta [Stylistics of the Text]. 416 p. [in Russian]

Domontovych, 1947 - Domontovych V. (1947). Doktor Serafikus [Doktor Seraficus]. 175 p. [in Ukrainian]

Kontorchuk, 2020 - Kontorchuk G., Remez A. Osoblyvosti poetychnoi onimii v romani V. Domontovycha «Doktor Serafikus». [Features of Poetic onymia in V. Domontovych's novel «Doctor Seraficus»]. URL: http://eprints.zu.edu.ua/id/ eprint/15770 (accessed : 12.10.2020). [in Ukrainian]

Korolova, 2003 - Korolova A. (2003). Lingvopoetychnyi i naratyvnyi kody intymizatsiyi v khudozhnomu teksti (na materiali ukrayinskoyi ta rosiyiskoyi prozu drugoi polovyny XIX - pershoi polovyny XX stolit). [Linguopoetic and Narrative Codes of Intimization in Belles-lettres Text (on the material of Ukrainian and Russian Prose of the II half of the XIX-th - the I half of the XX-th centuries)]. 53 p. [in Ukrainian]

Kukharenko, 2004 - Kukharenko V. (2004). Interpretatsiya tekstu. [Text interpretation]. 272 p. [in Ukrainian]

Literaturoznavchyi slovnyk, 2007 - Literaturoznavchyi slovnyk-dovidnyk. (2007). [Literary dictionary-reference book]. 751 p. [in Ukrainian]

Pavlychko, 1999 - Pavlychko S. (1999). Dyskurs modernizmu v ukrainskii literaturi. [The Discourse of Modernism in Ukrainian literature]. 447 p. [in Ukrainian]

Rozanova, 1996 - Rozanova E. (1996). Kompozicionno-rechevye formy v anglojazychnoj hudozhestvennoj i publicisticheskoj proze (sopostavitel'noe issledovanie na materiale proizvedenij XIX - XX vv. [Compositional Speech Forms in English Fiction and Publiciatic Prose (a comparative investigation based on the XIXth - XXth century works)]. 167 p. [in Ukrainian]

Fedurko, 2015 - Fedurko M. (2015). Vlasne imia v romani Viktora Domontovycha «Doctor Serafikus» : funktsii ta riznovydy. [The proper name in the novel by Victor Domontovych «Dr. Seraficus»: functions and varieties]. Problems of Humanities. Philology Series. Issue. 36, pp. 200-212. [in Ukrainian]

Shevelov, 2017 - Shevelov (Sherekh) Yu. (2017). Ya - mene - meni... (i dovkrugu). Spogady. 1. V Ukraini. [I - to me - me... (and around). Memoirs. 1. In Ukraine]. 728 p. [in Ukrainian] 
